\title{
MAKALAH
}

\section{INDONESIA DAN PERDAMAIAN DUNIA}

(KEWARGANEGARAAN)

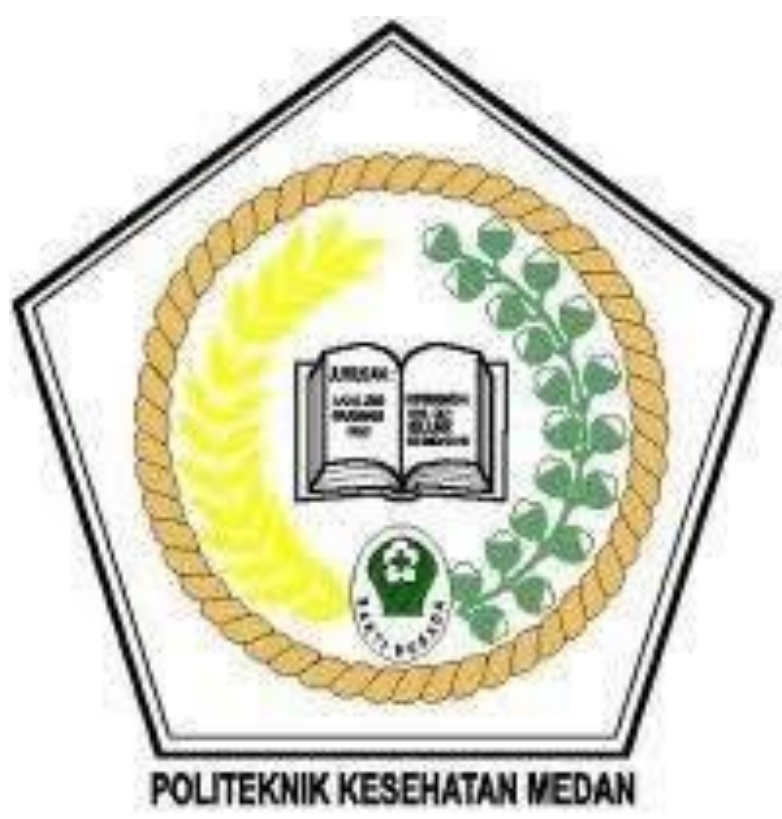

\section{DOSEN PENGAJAR}

Krista Surbakti S.Pd M.Si

\section{DISUSUN OLEH}

KELOMPOK 4 :

- Doharni Julianti Hutauruk (ketua)

- Dewi Sovianti Lubis

- Laura Deswarni Simanjuntak

- Komariyah

- Reynaldy Seftrico saragih

- Rizka Sopiana br Ginting

- Ratih Syeba Rotua br Situmorang

- Ummu Alfin karimah

POLITEKNIK KESEHATAN KEMENKES MEDAN

JURUSAN GIZI

$2019 / 2020$ 


\section{Daftar Isi}

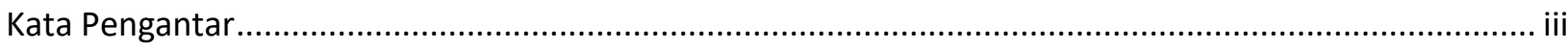

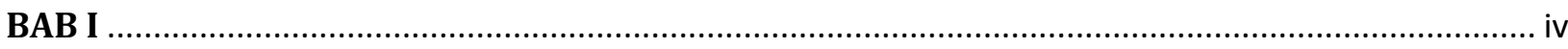

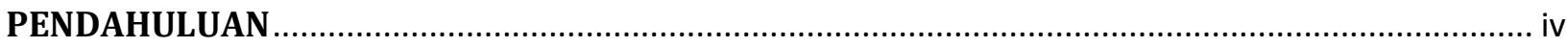

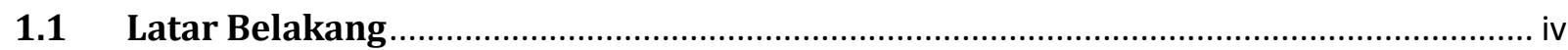

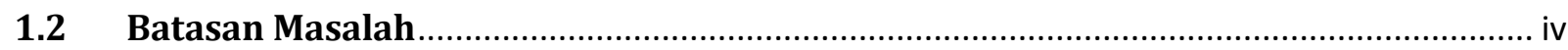

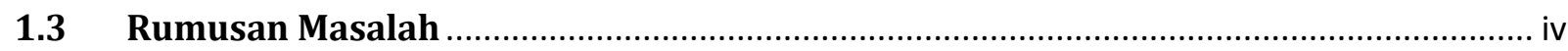

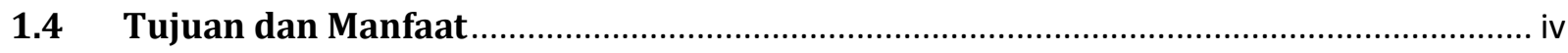

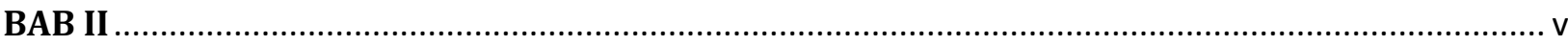

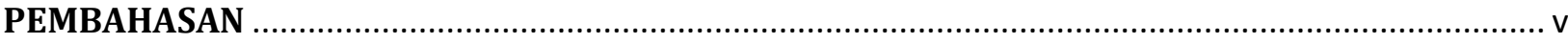

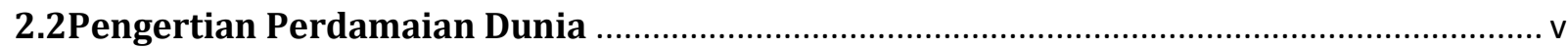

2.3Indonesia Dalam Perdamaian Dunia ................................................................................ v

2.4Partisipasi Indonesia dalam Perdamaian Dunia ........................................................... vi

2.4 Perwujudan Indonesia Dalam Perdamaian Dunia.................................................................. vi

- Melalui Pendekatan Cultural (Budaya) ....................................................................... vi

- Melalui Pendekatan Sosial dan Ekonomi ........................................................................ vii

- Melalui Pendekatan Politik........................................................................................ vii

- Melalui Pendekatan Religius (Agama) ........................................................................... vii

2.5 Indonesia dan Perserikatan Bangsa-Bangsa................................................................ viii

2.6Aktivitas Indonesia dalam Perserikatan Bangsa-Bangsa (PBB) ................................... viii

2.7 Peran Indonesia dalam Perdamaian Dunia................................................................... ix

2.8 Peranan Indonesia Dalam Membantu Menyelesaikan Konflik di berbagai Negara......... $x$

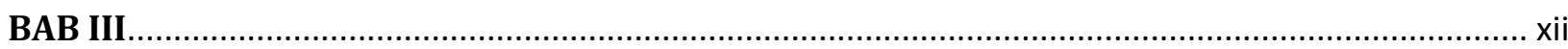

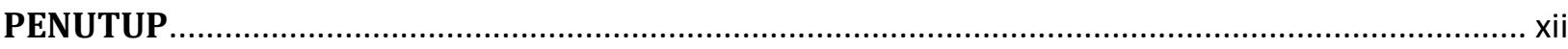

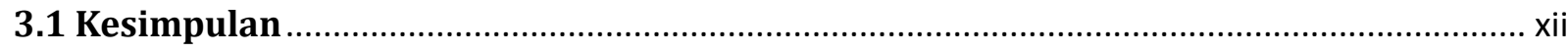

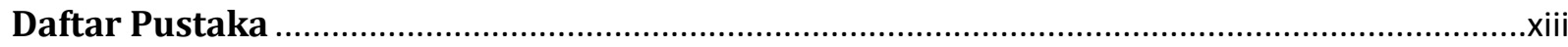




\section{Kata Pengantar}

Puji syukur kehadirat Tuhan Yang Maha Esa atas semua limpahan rahmat dan karunianya sehingga makalah dengan tema 'Indonesia Dalam Perdamaian Dunia' ini selesai dengan waktu yang tepat. Kami juga mengucapkan terimakasih kepada Bapak selaku guru pengajar mata kuliah Kewarganegaraan yang telah memberikan tugas ini kepada Bapak Krita Surbakti S.Pd M.Si kami sehingga kami mendapatkan banyak tambahan ilmu pengetahuan khususnya tentang Indonesia dalam Perdamaian Dunia

Kami selaku penyusun makalah ini, berharap semoga makalah yang telah Kami susun ini bisa memberikan banyak manfaat serta menambah ilmu pengetahuan terutama dalam hal Indonesia dalam Perdamaian Dunia

Karena keterbatasaan ilmu maupun pengalaman kami, kami yakin makalah ini masih banyak memiliki kekurangan yang membutuhkan perbaikan,oleh karena itu kami sangat berharap saran dan kritik yang membangun berasal dari Bapak dosen pengajar serta teman-teman sekalian demi kesempurnaan makalah ini.

Lubuk Pakam, 25 Oktober 2019

Penyusun 


\section{BAB I \\ PENDAHULUAN}

\subsection{Latar Belakang}

Dalam suatu Negara tidak dapat berdiri sendiri,seperti halnya individu sebagai makhluk sosial. Negara tentunya akan memerlukan Negara atau komponen yang lain .bahkan adapula Negara yang memiliki keterkaitan serta ketergantungan dalam aspek ekonomi,sosial,dan politik. Jika adanya keterkaitan antar Negara dengan Negara lain tersebut tentunya ada sebuah hubungan yang baik. Salah satunya merupakan Negara kita sendiri yaitu Negara Indonesia dengan Negara-negara lain.dinamakan masyarakat global, ditandai adanya saling ketergantungan antar bangsa, adanya persaingan yang ketat dalam suatu kompetensi dan dunia cenderung berkembang kearah perebutan pengaruh antar bangsa, baik lingkup regional maupun lingkup global.

Namun pada kenyataannya masih banyak hubungan yang bertentangan antara Negara satu dengan Negara yang lain. Yang mengakibatkan terjadinya konflik dan terusiknya perdamaian dunia. Konflik biasanya dipicu dengan adanya masalah dalam hal sosial,ekonomi,politik,agama maupu kebudayaan.terjadinya konflik akibat adanya keserakahan, kurang saling menghargai dan mengerti antara satu dengan yang lain. Dari masalah diatas dalam makalah ini akan membahas apa yang dimaksud dengan perdamaian dunia itu sendiri dan cara mewujudkan perdamaian dunia serta partisipasi Indonesia dalam perdamaian dunia.

\subsection{Batasan Masalah}

Pemakalah membatasi masalah agar makalah yang telah dibuat tidak terlalu banyak dan mudah dimengerti. Dan masalah yang akan dibahas yaitu tentang Perdamaian Dunia dan cara mewujudkan Perdamaian Dunia.

\subsection{Rumusan Masalah}

Berdasarkan latar belakang, berikut beberapa rumusan masalah yang akan kita bahas pada makalah ini :

- Apa Pengertian Dari Perdamaian Dunia

- Indonesia dalam Perdamaian Dunia

- Apakah Indoesia Turut Serta Dalam Perdamaian Dunia?

- Cara Mewujudkan Perdamaian Dunia

- Indonesia Dan Perserikatan Bangsa-Bangsa

- Peran Indonesia Dalam Perdamaian Dunia

\subsection{Tujuan dan Manfaat}

- Mengetahui Apa Sebenarnya Perdamaian Dunia

- Mengetahui Hubungan Indonesia Dalam Perdamaian Dunia

- Mengetahui Kontribusi Indonesia Dalam Perdamaian Dunia

- Mengetahui Bagaimana Cara Mewujudkan Perdamaian Dunia

- Mengetahui Organisasi-organisasi Perdamaian Dunia

- Mengetahui Peran Indonesia Dalam Perdamaian Dunia 


\section{BAB II \\ PEMBAHASAN}

\subsection{Pengertian Perdamaian Dunia}

Perdamaian Dunia adalah sebuah gagasan kebebasan, perdamaian, dan kebahagian bagi seluruh Negara dan bangsa.Perdamaian Dunia melintasi perbatasan melalui hak asasi manusia, teknologi, pendidikan, teknik, pengobatan, diplomat dan pengakhiran bentuk pertikaian. Sejak 1945, Perserikatan Bangsa-Bangsa dan lima anggota permanen Majelis Keamanannya (AS, Rusia, China, Prancis, dan Tritania Raya) bekerja untuk menyelesaikan konflik tanpa perang atau deklarasi perang. Namun, Negara-Negara telah memasuki sejumlah konflik militer sejak masa itu.

Perdamaian Dunia Dalam studi perdamaian, perdamaian dipahami dalam dua pengertian.Pertama, perdamaian adalah kondisi tidak adanya atau berkurangnya segala jenis kekerasan.Kedua, perdamaian adalah transformasi konflik kreatif non-kekerasan. Dari dua definisi di atas dapat disimpulkan bahwa perdamaian adalah apa yang kita miliki ketika transformasi konflik yang kreatif berlangsung secara tanpa kekerasan. Perdamaian selain merupakan sebuah keadaan, juga merupakan suatu proses kreatif tanpa kekerasan yang dialami dalam transformasi (fase perkembangan) suatu konflik. Umumnya pemahaman tentang kekerasan hanya merujuk pada tindakan yang dilakukan secara fisik dan mempunyai akibat secara langsung.Batasan seperti ini terlalu minimalistis karena rujukannya berfokus pada peniadaan atau perusakan fisik semata.Kendati pun demikian, pengertian perdamaian tidak berhenti di situ.Perdamaian bukan sekedar soal ketiadaan kekerasan atau pun situasi yang anti kekerasan.Lebih jauh dari itu perdamaian seharusnya mengandung pengertian keadilan dan kemajuan. Perdamaian dunia tidak akan dicapai bila tingkat penyebaran penyakit, ketidakadilan, kemiskinan dan keadaan putus harapan tidak diminimalisir. Perdamaian bukan soal penggunaan metode kreatif nonkekerasan terhadap setiap bentuk kekerasan, tapi semestinya dapat menciptakan sebuah situasi yang seimbang dan harmoni, yang tidak berat sebelah bagi pihak yang kuat tetapi sama-sama sederajat dan seimbang bagi semua pihak. Jadi perdamaian dunia merupakan tiadanya kekerasan, kesenjangan, terjadinya konflik antar negara di seluruh dunia.

\subsection{Indonesia Dalam Perdamaian Dunia}

Indonesia dalam Perdamaian Dunia ditegaskan dalam pembukaan Undang-Undang Dasar 1945 yang berbunyi : "Bahwa sesungguhnya kemerdekaan itu adalah hak segala bangsa dan oleh sebab itu maka penjajahan diatas dunia harus dihapuskan, karena tidak sesuai dengan perikemanusiaan dan perikeadilan". Dalam alenia keempat pembukaan Undang-Undang dasar '45 dengan meletakkan kewajiban atas pemerintahan untuk serta melaksanakan ketertiban dunia yang berdasarkan kemerdekaan, perdamaian abadi dan keadilan sosial.Pernyataan Indonesia dalam perdamaian dunia juga termasuk kedalam tujuan bangsa Indonesia. 


\subsection{Partisipasi Indonesia dalam Perdamaian Dunia}

Indonesia disebut sebagai sebuah negara yang memiliki peran penting dalam perdamaian dunia.Hal ini dikarenakan Indonesia menjadi negara demokrasi terbesar ketiga di dunia. Selain itu, juga menjadi negara dengan penduduk muslim terbesar di dunia, dan menjadi negara penyumbang personel misi pemeliharaan perdamaian Perserikatan Bangsa-Bangsa terbesar ke-12 dari 122 negara dengan 2.764 personel.

Indonesia tidak hanya memiliki peran penting dalam mewujudkan perdamaian dunia karena sistem dan jumlah umat muslimnya yang terbanyak.Akan tetapi, peran tersebut juga turut tercermin pada setiap kedutaan Indonesia di luar negeri.Dari kedutaan-kedutaan tersebut, tercermin bahwa Indonesia tidak mengklasifikasikan keistimewaan tertentu bagi masing-masing perwakilan negaranya di luar.Dengan adanya kedutaan-kedutaan Indonesia di luar negeri itu pula, sebenarnya kita memiliki kesempatan untuk bisa ikut berperan dalam mewujudkan perdamaian dunia.

Jika dalam politik luar negeri bebas aktif, tujuan dari bebas yaitu untuk menentukan sikap dan kebijaksanaan terhadap permasalahan internasional, dan tidak mengikatkan diri secara apriori pada satu kekuatan dunia.Selain itu, sebuah negara juga memiliki kesempatan untuk turut aktif memberikan sumbangan, baik dalam bentuk pemikiran maupun partisipasi aktif dalam menyelesaikan konflik, sengketa dan permasalahan dunia lainnya, demi terwujudnya ketertiban dunia yang berdasarkan kemerdekaan, perdamaian abadi dan keadilan sosial.

\subsection{Perwujudan Indonesia Dalam Perdamaian Dunia}

Menurut Cipto Wardoyo yang harus dilakukan demi mewujudkan perdamaian dunia, antara lain:

\section{- Melalui Pendekatan Cultural (Budaya)}

Menurut penulis untuk mewujudkan perdamaian kita harus mengetahui budaya tiap-tiap masyarakat ataupun sebuah Negara. Jika tidak akan percuma saja segala upaya kita. Dengan mengetahui budaya tiap-tiap masyarakat atau sebuah Negara maka kita bisa memahami karakteristik dari masyarakat atau Negara tersebut.Atas dasar budaya dan karakteristik masyarakat atau suatu Negara, kita bisa mengambil langkah-langkah yang tepat dan efektif dalam mewujudkan perdamaian disana. Menurut penuulis pendekatan budaya ini merupakan cara yang paling efektif dalam mewujudkan perdamaian di masyarakat Indonesia serta dunia. 


\section{- Melalui Pendekatan Sosial dan Ekonomi}

Dalam hal ini pendekatan sosial dan ekonomi yang penulis maksudkan terkait masalah kesejahteraan dan factor-factor sosial di masyarakat yang turut berpengaruh terhadap upaya perwujudan perdamaian dunia.Ketika masyarakatnya kurang sejahtera tentu saja lebih rawan konflik dan kekerasan di dalamnya. Masyarakat atau Negara yang kurang sejahtera biasanya akan "cuek" atas isu dan seruan perdamaian. "Boro-boro mikirin perdamaian dunia, buat makan untuk hidup sehari-hari saja susahnya minta ampun", begitu fikir mereka yang kurang sejahtera.Maka untuk mendukung upaya perwujudan perdamaian dunia yang harus dilakukan terlebih dahulu adalah meningkatkan pemerataan kesejahteraan seluruh masyarakat dan Negara di dunia ini.

\section{- Melalui Pendekatan Politik}

Menurut analisis penulis, melalui pendekatan budaya dan sosial ekonomi saja belum cukup efektif untuk mewujudkan perdamaian dunia.Perlu adanya campur tangan politik, dalam artian ada agenda politik yang menekankan dan menyerukan terwujudnya perdamaian dunia.Terlebih lagi bagi Negara-negara maju dan adidaya yang memiliki power atau pengaruh dimata dunia.Negara-negara maju pada saat-saat tertentu harus berani menggunakan power-nya untuk "melakukan sedikit penekanan" pada Negara-negara yang saling berkonflik agar bersedia berdamai kembali.Bukan justru membuat situasi semakin panas, dengan niatan agar persenjataan mereka terus dibeli.

Ini tentu sekali lagi butuh kesadaran dan komitmen bersama.Yang jadi pertanyaan dibenak penulis terhadap Negara-negara adidaya, katanya cinta damai tapi mengapa terus berlomba-lomba membuat senjata perang yang super canggih dan mematikan yang bersifat masal.

\section{- Melalui Pendekatan Religius (Agama)}

Pada hakikatnya seluruh umat beragama di dunia ini pasti menginginkan adanya perdamaian.Sebab saya kira tidak ada agama yang mengajarkan kejahatan, kekerasan ataupun peperangan.Semua Negara mengajarkan kebaikan, yang diantaranaya kepedulian dan perdamaian.Maka dari itu setiap kita yang mengaku beragama dan berTuhan tentu harus memiliki kepedulian dalam turut serta mewujudkan perdamaian di masyarakat maupun di kancah dunia. Para tokoh agama yang dianggap memiliki charisma dan pengaruh besar di masyarakat harus ikut serta aktif menyerukan perdamaian 


\subsection{Indonesia dan Perserikatan Bangsa-Bangsa}

Perserikatan Bangsa-Bangsa disingkat sebagai PBB adalah organisasi Internasional yang didirikan pada tanggal 24 Oktober 1945 untuk mendorong kerjasama internasional.Badan ini merupakan pengganti Liga Bangsa Bangsa dan didirikan setelah Perang Dunia II untuk mencegah terjadinya konflik serupa.Pada saat didirikan, PBB memiliki 51 negara anggota; saat ini terdapat 193 anggota. Selain negara anggota, beberapa organisasi internasional, dan organisasi antar-negara mendapat tempat sebagai pengamat permanen yang mempunyai kantor di Markas Besar PBB, dan ada juga yang hanya berstatus sebagai pengamat.[2] Palestina dan Vatikan adalah negara bukan anggota (non-member states) dan termasuk pengamat permanen (Tahta Suci mempunyai wakil permanen di PBB, sedangkan Palestina mempunyai kantor permanen di PBB.

Indonesia resmi menjadi anggota Perserikatan Bangsa-Bangsa ke-60 tanggal 28 September 1950, yang ditetapkan dengan resolusi Majelis Umum PBB Nomor A/RES/491 (V) tentang "Penerimaan Republik Indonesia dalam keanggotaan di PBB".Kurang dari satu tahun setelah pengakuan kedaulatan Indonesia oleh belanda dalam konferensi Meja Bundar di Den Haag (23 Agustus - 2 November, 1949).

Pada masa konfrontasi Indonesia - Malaysia pada Januari 1965, sebagai reaksi atas terpilihnya Malaysia sebagai anggota tidak tetap dewan keamanan PBB, Soekarno marah, Indonesia memutuskan untuk mundur dari PBB. Namun, dalam sebuah telegram bertanggal 19 September 1966, Indonesia memberikan pesan kepada sekertaris Jenderal PBB atas keputusannya "Untuk melanjutkan kerja sama penuh dengan PBB, dan untuk melanjutkan partisipainya dalam sesi ke- 21 sidang Majelis.

\subsection{Aktivitas Indonesia dalam Perserikatan Bangsa-Bangsa (PBB)}

- Majelis Umum PBB, Indonesia menjadi anggota Majelis Umum PBB semenjak tahun 1951. Indonesia pernah sekali ditunjuk sebagai presiden Majelis Umum PBB pada tahun 1971, yang pada saaat itu diwakili oleh Adam Malik yang memimpin sesi ke-26 sidang Majelis Umum PBB.

- Dewan Keamanan PBB, Indonesia telah terpilih sebanyak empat kali sebagai anggota tidak tetap di dewan keamanan PBB.

- Dewan Ekonomi dan Sosial PBB, Indonesia menjadi angggota Dewan Ekonomi dan Sosial PBB untuk 11 priode. Indonesia pernah dipilih dua kali sebagai presiden Dewan Ekonomi dan Sosial PBB pada tahun 1970 dan 2000 dan dipilih sebagai wakil pada tahun 1969, 1999,dan 2012.

- Dewan Hak Asasi Manusia PBB, Indonesia telah terpilih sebanyak tiga kali sebagai anggota Dewan Hak Asasi Manusia PBB semenjak Dewan tersebut dibentuk pada tahun 2006. 


\section{Adapun tujuan dari Perserikatan Bangsa-Bangsa adalah sebagai beriku :}

- menjaga perdamaian dan keamanan dunia,

- memajukan dan mendorong hubungan persaudaraan antarbangsa melalui penghormatan hak asasi manusia,

- membina kerjasama internasional dalam pembangunan bidang ekonomi, sosial, budaya, dan lingkungan,

- menjadi pusat penyelarasan segala tindakan bersama terhadap negara yang membahayakan perdamaian dunia, dan

- menyediakan bantuan kemanusiaan apabila terjadi kelaparan, bencana alam, dan konflik bersenjata

\subsection{Peran Indonesia dalam Perdamaian Dunia}

Kontribusi Indonesia dalam menjaga perdamaian dunia :

\section{Konferensi Asia-Afrika}

Indonesia menjadi salah satu pelopor tercetusnya konferensi Asia-Afrika yang tujuannya adalah menghimpun persatuan Negara-negara Asia-Afrika yang pada saat itu baru memperoleh kemerdekaan, mempromosikan serta meningkatkan kerja sama antar Negara serta menentang segala bentuk penjajahan.

Konferensi ini dipelopori oleh menteri luar negeri Indonesia pada saat itu, Ali sastromidjojo, beserta 4 pemimpin Negara lainnya Pakista,India,Bangladesh, dan Myanmar yang kemudian diikuti 24 negara Asia-Afrika lainnya.

\section{Kontingen Garuda (1957-sekarang)}

Kontingen Garuda adalah pasukan penjaga perdamaian yang anggotanya diambil dari militer Indonesia yang bertugas dibawah naugan Perserikatan Bangsa-bangsa.Sejak misi pertamanya tahun 1957, Kontingen garuda sampai sekarang masih aktif dalam melakukan berbagai misi perdamaian.

Negara-negara yang pernah menjadi tujuan dalam misi Kontingen Garuda adalah Negara-negara di Timur Tengah seperti Mesir,Lebanon,Palestina,Irak. Negara Asean seperti Filipina,kamboja,dan Vietnam. Juga Negara Eropa Timur seperti Georgia dan Bosnia.

\section{Gerakan Non-Blok (1961)}

Indonesia menjadi salah satu pelopor yang tergabung dalam gerakan Non-Blok, sebuah perhimpunan dari bangsa-bangsa yang tidak beraliansi dengan Negara-negara dengan kekuatan besar manapun. Pada saat itu Soekarno bersama dengan beberapa pemimpin Negara lainnya mendeklarasikan keinginan mereka untuk tidak terlibat kobnfrontasi yang muncul menanggapi terjadinya perang dingin antara blok barat dan blok timur. Saat ini organisasinya beranggotakan 120 negara 


\section{Membentuk ASEAN (1967)}

Indonesia dan Malaysia yang sempat berkonfrontasi akhirnya berdamai.Kedua Negara bersama Asia Tenggara lainnya, Singapura, Thailand, Filipina merasa perlu untuk menciptakan perdamaian antar Negara dikawasan Asia Tenggara. Akhirnya pada tahun 1967 terbentuklah ASEAN untuk mempererat hubungan politik,sosial,ekonomi,dan keamanan di Asia Tenggara. Saat ini Negara ASEAN berjumlah 10 negara ditambah dengan 5 negara perluasan.

\section{Sangketa Laut Tiongkok (2002-sekarang)}

Melalui Declaration Of Conduct (DOC) pada 2002, Indonesia sampai sekarang memiliki peran yang besar untuk menciptakan perdamaian di Laut Cini Selatan.Indonesia pada akhirnya menginginkan Negara-negara yang terlibat untuk merumuskan Code Of Conduct, yaitu sebuah kesepakatan bersama yang mengatur apa saja dan tidak boleh dilakukan diwilayah sangketa.

\section{Anggota Tidak Tetap Dewan Keamanan PBB (2007-2008)}

Indonesia menjadi anggota tidak tetap Dewan Keamana PBB pada tahun 20072008, pada masa tersebut Indonesia konsisten menyerukan untuk berdirinya Negara Palestina yang merdeka dan di akui dunia. Menyerukan keterlibatan Internasional yang berimbang dalam penyelesaian konflik Israel-Palestina.Menyerukan agar kedua belah mematuhi parlementer perdamaian yang ditetapkan PBB.

\subsection{Peranan Indonesia Dalam Membantu Menyelesaikan Konflik di berbagai Negara}

- Thailand Berdamai saat Era Soeharto

Perdamaian Thailand berawal pada awal periode 1980-an, saat Presiden Filipina Ferdinand Marcos berusaha mencari dukungan dari negara-negara Timur Tengah dan Indonesia untuk menyelesaikan konflik dengan Bangsa Moro di Mindanau.Saat itu Moro ingin merdeka dan memisahkan diri dari Filipina.

\section{- Konflik Perbatasan Thailand dan Kamboja}

Indonesia sebagai ketua ASEAN menggelar Informal ASEAN Foreign Minister's Meeting (pertemuan informal para Menlu ASEAN) dengan agenda tunggal pembahasan penyelesaian konflik Thailand dan Kamboja. Konflik kedua negara terjadi di satu kuil kuno di perbatasan kedua negara yang disengketakan.

Dalam pertemuan itu membahas perdamaian Thailand dan Kamboja.Indonesia sebagai mediator tercapai ketika Menteri Luar Negeri Marty Natalegawa mampu mendamaikan kedua negara di PBB pada 14 Februari 2011.

Indonesia kemudian membawa masalah Mindanau ke Forum Menteri Luar Negeri Negara Muslim. Dibentuk Komite Enam, dengan Indonesia sebagai ketuanya.

Indonesia dipilih karena menjadi negara Muslim terbesar, punya kepemimpinan yang kuat di kawasan ASEAN dan punya pengalaman menengahi konflik di Kamboja. 
- Konflik Kamboja dan Vietnam

Pada tahun 1988 sampai 1989, Indonesia pernah menjadi tuan rumah Jakarta Informal Meeting (JIM) untuk menyelesaikan konflik antara Kamboja dan Vietnam.

Pada saat itu Indonesia berhasil memfasilitasi dan memediasi kedua negara yang sedang bermusuhan untuk bisa duduk bersama-sama mendiskusikan dan menyelesaikan konflik diantara mereka.

Hasilnya, Vietnam menarik pasukannya dari Kamboja dan situasi damai di Kamboja tercipta.

- Konflik Etnis Rohingya dengan Myanmar

Konflik yang masih terjadi hingga menjadi perbincangan luar negeri adalah konflik etnis Rohingya dengan Myanmar.Banyak yang beranggapan bahwa pemimpin de facto Myanmar, Aung San Suu Kyi tak banyak berperan dalam menyelesaikan konflik teraebut.

Indonesia turut membantu menyelesaikan masalah ini.Sudah beberapa kali Menteri Luar Negeri Retno Marsudi mengunjungi Myanmar dan Bangladesh untuk membicarakan perdamaian Myanmar dengan Rohingya. 


\section{BAB III \\ PENUTUP}

\subsection{Kesimpulan}

Hubungan dan kerjasama antara bangsa muncul karena tidak meratanya pembagian kekayaan alam dan perkembangan industri diseluruh dunia sehingga terjadi saling ketergantungan antara bangsa dan Negara yang berbeda. Karena hubungan dan kerjasama ini terus menerus, sangatlah penting untuk memelihara dan mengaturnya sehingga bermanfaat dalam pengaturan khusus sehingga tumbuh rasa persahabatan dan saling pengertian antara bangsa di dunia.politik luar negeri adalah strategi yang digunakan suatu Negara dalam hubungannya dengan Negara-negara lain. Maka politik luar negeri berhubungan erat dengan kebijakan yang akan dipilih oleh suatu Negara. Hal ini terkait dengan politik luar negeri yang diterapkan Indonesia.Kebijakan politik luar negeri Indonesia bebas aktif tentunya merupakan strategi politik yang diterapkan Indonesia dalam politik global.Agar prinsip bebas aktif ini dapat dioperasioalisasikan dalam politik luar negeri Indonesia maka setiap priode pemerintahan hendaklah menetapkan landasan operasional.Politik luar negeri Indonesia yang senantiasa berubah sesuai dengan kepentingan nasional.

Perumusan politik luar negeri suatu Negara tak terlepas dari kepentingan nasional Negara yang bersangkutan. Dengan kata lain, ketika kepentingan nasional suatu Negara terancam, maka politik luar negeri akan dikeluarkan sebagai salah satu upaya dalam mengamankan kepentingan ansional Negara yang bersangkutan. Sengketa internasional adalah suatu perselisihan antara subyek-subyek hokum internasional mengenai fakta,hokum atau politi dimana tuntutan atau pernyataan suatu pihak ditolak,dituntut balik atau diigkari oleh pihak lainnya. 


\section{Daftar Pustaka}

Indonesia dalam Perdamaian Dunia,diperoleh pada tanggal 23 oktober 2019 dari https://id.m.wikipedia.org/wiki/perdamaian-dunia

Indonesia dan Perserikatan Bangsa-Bangsa diperoleh pada tanggal 23 oktober 2019 dari https://pendidikanmu.com/2018/11/konferensi-asia-afrika-dan-peran-idonesiaterlengkap

Kontribusi Indonesia dalam Perdamaian Dunia, diperoleh pada tanggal 23 oktober 2019 dari https://guruppkn.com/peran-indonesia-dalam-kaa

Peran Indonesia Dalam Perdamaian Dunia diperoleh pada tanggal 23 oktober dari https://guruppkn.peran-indonesia-dalam-gerakan-non-blok

Pengertian Perdamaian Dunia,diperoleh pada tanggal 23 oktober 2019 dari https://id.m.wikipedia.org/wiki/perdamaian-dunia

Perwujudan Indonesia Dalam Perdamaian Dunia diperoleh pada tanggal 23 oktober 2019 dari https://zettabloks.blogspot.com/2016/03/pengertian-latar-belakang-dan-tujuanperdamaian-dunia

Surbakti, K. (2018). PENGARUH FASILITAS BELAJAR TERHADAP HASIL BELAJAR SISWA PADA MATA PELAJARAN PKN KELAS VIII MTSN KABANJAHE TAHUN PELAJARAN 2017/2018. In Prosiding Seminar Nasional Sains Teknologi Humaniora dan Pendidikan (QSinastekmapan) (Vol. 1).

Surbakti, K. (2018). UPAYA MENINGKATKAN HASIL BELAJAR PKN SISWA DENGAN MENGGUNAKAN MODEL TALKING STICK MATERI SISTEM PEMERINTAHAN PUSAT. JURNAL TEMATIK, 8(1), 166-171. 